\title{
Effect of Precooking on the Quality of Instant Flakes from Florido Yam (Dioscorea alata L.) ${ }^{1}$
}

\author{
E. J. Rodriguez-Sosa, M. A. González, and O. Parsi-Ros ${ }^{2}$ \\ INTRODUCTION
}

Yam is one of the most extensively cultivated root crops in the tropical world. More than 20 million tons are harvested per year. Production in Puerto Rico is on the order of 280,000 hundredweights and valued at $\$ 3.36$ millions (4). The two most important commercial varieties grown in Puerto Rico are Florido (Dioscorea alata) and Habanero (Dioscorea rotundata).

Previous investigations on yam conducted at the Food Technology Laboratory of the University of Puerto Rico include the following: storage (5), lye peeling (9), processing of instant flakes $(10,11)$, processing and shelflife study of yam chips (12), pasting characteristics of extracted starch (3), and the effect of flake size on pasting characteristics of slurries prepared therefrom (13).

It is generally recognized that texture, or mouth-feel, is one of the major attributes of food quality affecting consumer acceptance. According to Smith and Davis (15), consistency is the most important textural factor in processed white potatoes. Hall and Fryer (6) suggested that cell rupture results in the release of the free starch from the plant cell with a resultant poor consistency. In the preparation of mashed potatoes, the precooking of potato slabs is necessary to control the cell rupture in the final product (2).

The Brabender Amylograph-Viscograph, currently known as a Starch Tester, has been the instrument used most extensively to measure changes in consistency which occur during heating, cooking, and cooling starch and starchy-flour slurries.

As yam and white potato starches have different characteristics, precooking of yam was attempted to control cell rupture and thus assure good quality instant flakes. The results obtained are reported herein.

\section{MATERIALS AND METHODS}

Instant flakes were prepared from Florido yam essentially as described by Rodríguez-Sosa and González (10). The method consists of the following steps: Washing the yams, peeling for 4 minutes in a 20-percent boiling lye solution, brushing in a rotary washer provided with water sprayers to re-

1 Manuscript submitted to Editorial Board December 10, 1973.

2 Assistant Food Technologist, Technical Director, and Research Assistant, respectively, Food Technology Laboratory, Agricultural Experiment Station, Mayagüez Campus, University of Puerto Rico, Rio Piedras, P.R. 
move any peel left, and trimming and slicing into about 1/2-inch slabs. The slabs were precooked in water at $160^{\circ} \mathrm{F}\left(71.1^{\circ} \mathrm{C}\right)$ for $5,10,15,20$, and 25 minutes. After precooking, the slabs were soaked for 10 minutes in a 0.1percent potassium metabisulfite solution to inhibit browning reactions. The slabs were then steam-cooked for 15 minutes, mashed, total solids adjusted to about 20 percent, and dehydrated in a double drum dryer. The drums were heated with steam at a pressure of 60 pounds in ${ }^{2}$, speed and clearance were adjusted to $2.5^{\circ} \mathrm{r} / \mathrm{min}$ and $0.008 \mathrm{inch}$, respectively. The resulting dehydrated flakes were forced through a $5 / 16$-inch $(8.00 \mathrm{~mm})$ mesh screen. The samples retained on No. $8(2.38 \mathrm{~mm})$ mesh screens were packed in tin cans and stored at ambient conditions until used.

Yam flakes were analyzed to determine the free soluble starch as a blue value index (BVI) according to the method developed by Mullins et al. (7). The samples were left overnight in a vacuum oven at $48^{\circ} \mathrm{C}$ to standardize the moisture content prior to the BVI analyses.

Yam flake slurries were prepared for viscosity measurements as described in a previous publication (13). The measurements were taken using the Brabender Amylograph-Viscograph.

Shear press measurements were taken on yam slurries after amylographic determination. A Texture Test System provided with a Universal Cell, a snugly fitted piston and a bottom plate with an orifice of 0.062 inch together with a 300-pound proving ring with range adjusted to 20 percent was used. The stroke of the press was adjusted to 1 minute. Measurements were taken on 200-g samples at room temperature. The area under the curve was measured with a planimeter.

\section{RESULTS AND DISCUSSION}

The pasting characteristics of instant Florido yam as affected by precooking are presented in table 1 . The pasting temperature of the flake slurries showed a tendency to increase with the increase in precooking time while the initial viscosity (taken at $30^{\circ} \mathrm{C}$ ) decreased. All other viscosity measurements taken at different points showed a tendency to decrease with the increase in precooking time. The abnormally higher pasting measurements of samples precooked for 15 minutes might be explained in terms of a combination of precooking time and BVI. These samples had a higher BVI (table 2) than samples precooked for 10 minutes.

Unmodified extracted yam starch, upon amylography, showed no peak viscosity denoting its strength (8). Yam starch, with its high content of amylose (as high as 35 percent) is very stable. The amylose mechanically reinforces the swollen granule. However, yam flake slurries prepared from unprecooked slabs and sifted at different flake sizes showed moderate peak viscosity (13). That behavior was explained in terms of possible changes in 
starch due to the heating process; i.e., steam-cooking and dehydration. Nevertheless, no peak viscosity was observed when yam slabs were precooked. Precooking, provoking a partial gelatinization of the starch, prevents its breakage, giving the necessary strength to the granules. This is confirmed by the BVI which is lower at higher precooking times (table 2).

Irrespective of the precooking time, yam flake slurries showed a fairly high stability while cooking at $92^{\circ} \mathrm{C}$ for 1 hour (difference between vis-

TABLE 1.-Pasting characteristics of instant Florido (D. alata) yam fake slurries prepared from yam tubers precooked in water at $160^{\circ} \mathrm{F}$

\begin{tabular}{ccccccc}
\hline \multirow{2}{*}{$\begin{array}{c}\text { Precooking } \\
\text { time }\end{array}$} & $\begin{array}{c}\text { Pasting } \\
\text { temperature }\end{array}$ & $\begin{array}{c}\text { Initial at } \\
30^{\circ} \mathrm{C}\end{array}$ & $\begin{array}{c}\text { On reaching } \\
92^{\circ} \mathrm{C}\end{array}$ & $\begin{array}{c}\text { After 1 hour } \\
\text { at } 92^{\circ} \mathrm{C}\end{array}$ & $\begin{array}{c}\text { On reaching } \\
50^{\circ} \mathrm{C}\end{array}$ & $\begin{array}{c}\text { After } 1 \text { hour } \\
\text { at } 50^{\circ} \mathrm{C}\end{array}$ \\
\hline Minules & ${ }^{\circ} \mathrm{C}$ & & & & & \\
5 & 68 & 157 & 83 & 112 & 330 & 337 \\
10 & 74 & 150 & 62 & 80 & 265 & 270 \\
15 & 74 & 115 & 65 & 95 & 275 & 282 \\
20 & 75 & 107 & 45 & 80 & 225 & 238 \\
25 & 88 & 53 & 3 & 59 & 160 & 163 \\
\hline
\end{tabular}

$\because 1$ Viscosity was measured in Brabender units.

TABLE 2.-Blue valve index (BVI) of instant Florido (D. alata) yam flakes prepared from yam tubers precooked in water at $160^{\circ} \mathrm{F}$ and shear press measurements of flake slurries taken after amylography

\begin{tabular}{ccccccc}
\hline \multirow{2}{*}{$\begin{array}{c}\text { Precooking } \\
\text { time }\end{array}$} & Blue valve index & \multicolumn{5}{c}{ Shear Press measurements } \\
\cline { 3 - 7 } & $\begin{array}{c}\text { Area } \\
\text { under the } \\
\text { curve }\end{array}$ & $\begin{array}{c}\text { Ascending } \\
\text { line length }\end{array}$ & $\begin{array}{c}\text { Descending } \\
\text { line length }\end{array}$ & $\begin{array}{c}\text { Peak } \\
\text { height }\end{array}$ & $\begin{array}{c}\text { Number } \\
\text { of peaks }\end{array}$ \\
\hline Minules & & Square inches & Inches & Inches & Pounds \\
5 & 227 & 3.21 & $18 / 16$ & $1 \% / 16$ & 54 & 22 \\
10 & 206 & 3.07 & $14 / 16$ & $1 \% / 16$ & 62.6 & 21 \\
15 & 227 & 2.66 & $13 / 16$ & $15 / 16$ & 53.6 & 20 \\
20 & 114 & 2.15 & $11 / 16$ & 1 & 52.3 & 17 \\
25 & 98 & 1.40 & $7 / 16$ & $1 / 16$ & 25.1 & 2 \\
\hline
\end{tabular}

cosity after cooking for 1 hour at $92^{\circ} \mathrm{C}$ and viscosity upon reaching $92^{\circ} \mathrm{C}$ ) and a great stability while cooking at $50^{\circ} \mathrm{C}$ (difference between viscosity after cooking for 1 hour at $50^{\circ} \mathrm{C}$ and viscosity upon reaching $50^{\circ} \mathrm{C}$ ). At higher BVI, mashes were stickier and showed higher viscosity measurements.

Yam slurries after amylography essentially are gels. Those of samples prepared from yam slabs precooked for longer periods were less viscous because less starch was available for gelatinization. As mentioned, the starch is partially gelatinized during the precooking treatment. The degree 
of gelatinization depends on the water temperature and precooking time. Shear press measurements of yam slurries after amylography are shown in table 2. As precooking time of yam slabs increased, the area under the shear press curve of flake slurries after amylography decreased. Differences among successive samples were higher at longer precooking times denoting that the treatment has a great effect on starches. A larger area under the curve indicates more gelatinization, or stronger gels, as more work is needed to break and extrude the gel through the orifice plate of the Universal Cell.

The ascending and descending portion of the shear press curves were almost perpendicular to the base line and they decreased with an increase in precooking time. The initial peak is an indication of the strength of the gel, as it is the force needed to push the sample down tightly. Yam slurries after amylography of longer precooking times had softer gels. The even plateau of the curve of samples precooked for 25 minutes was interrupted only by a few peaks, while at shorter precooking times the number of sharp peaks was greater. This uneven plateau represents the force required to extrude the material through the orifice in the bottom plate inserted in the Universal Cell (1). The highest peak can be used as an index of firmness. As shown in table 2, peak height tended to decrease with an increase in the precooking time of yam slabs. In gelled yam slurries it might be expected that fibers passing through the 0.062-inch orifice have some influence in peak height and number.

The free soluble starch, liberated during processing, is responsible for the stickiness of products such as mashed yam. As demonstrated by this study, precooking of the raw yam was successfully used to reduce this undesirable property.

\section{SUMMARY}

Pasting characteristics of instant Florido (D. alata $L$.) yam flake slurries were studied using the Brabender Amylograph-Viscograph. Instant flakes were prepared from yam tubers precooked at different time intervals. Pasting temperature of the flake slurries tended to increase with an increase in precooking time while the Brabender viscosity measurements tended to decrease. No peak viscosity was observed, denoting the strength of yam starch. Samples showed great stability while cooking at $92^{\circ}$ and $50^{\circ} \mathrm{C}$ for 1 hour. The blue value index (BVI) and shear press measurements decreased with the increase in precooking time. Therefore, precooking of raw yam proved to be helpful in reducing the free soluble starch in the instant yam flakes, thus reducing the stickiness of the end product.

\section{RESUMEN}

Se estudiaron las características de pastosidad exhibidas por mezclas acuosas preparadas de hojuelas instantáneas de ñame Florido (D. alata L.), precocinando los 
tubérculos por distintos periodos de tiempo. Para hacer el estudio se usó el AmiloViscógrafo Brabender. La temperatura de empaste de las mezclas tendió a subir al aumentarse el periodo de precocción de los tubérculos, en cambio, el grado de viscosidad, según fue medida por el amilógrafo, tendió a disminuir. No se observó un pico de viscosidad, demostrándose la fortaleza del almidón de ñame. El almidón mostró una gran estabilidad en el amilógrafo mientras se cocinaba por 1 hora a $92^{\circ}$ y $50^{\circ} \mathrm{C}$. El índice de valor azul (blue value index) y la textura según fue medida tendieron a disminuir al aumentarse el período de precocción de los tubérculos. Por lo tanto, la precocción del ñame ayuda a reducir la cantidad de almidón libre en las hojuelas instantíneas, reduciendo así la pastosidad del producto final.

\section{LITERATURE CITED}

1. Bourne, M. C., Moyer, J. C., and Hand, D. B., Measurement of food texture by a Universal Testing Machine, Food Technol. 20 (4): 170-4, 1966.

2. Cording, J. Jr., and Willard, M. J. Jr., Method for control of texture of dehydrated potatoes, U.S. Pat. No. 2,787,553, Apr. 2, 1957 pp.

3. Cruz-Cay, J. R., and Gonzflez, M. A., Properties of Florido (Dioscorea alala L.) yam starch, J. Agr. Univ. P.R. 58 (3) : 312-16, 1974.

4. Fact Sheet on Puerto Rico's Agriculture, Agr. Exp. Sta., College Agr. Sci., Univ. P.R., 1971.

5. Gonzalez, M. A., and Collazo de Rivera, A., Storage of fresh yams (Dioscorea alata) under controlled conditions, J. Agr. Univ. P.R. 51 (1) : 46-56, 1972.

6. Hall, R. C., and Fryer, H. C., Consistency evaluation of dehydrated potato granules and directions for microscopic rupture count procedure, Food Technol. 7 (9): 373-6, 1953.

7. Mullins, W. R., Harrington, W. O., Olson, R. L., Wood, E. R., and Nutting, M. D., Estimation of free starch in potato granules and its relation to consistency of reconstituted product, Food Technol. 9 (8): 393-5, 1955.

8. Rasper, V., Investigations on starches from major starch crops grown in Ghana I. Hot paste viscosity and gel-forming power, J. Sci. Fd. Agr. 20 (3): 165-71, 1960.

9. Rivera-Ortíz, J. M., and González, M. A., Lye peeling of fresh yams (Dioscorea alata), J. Agr. Univ. P.R., 56 (1): 57-63, 1972.

10. Rodríguez-Sosa, E. J., and González, M. A., The preparation of yam (Dioscorea alata) flakes, J. Agr. Univ. P.R., 56 (1): 39-45, 1972.

11. - González, M. A., and Martin, F. W., Evaluation of ten varieties of yam (Dioscorea spp.) for production of instant flakes, J. Agr. Univ. P.R., 56 (3) : 23543, 1972.

12. - Cruz-Cay, J. R., González, M. A., and Martin, F. W., Shelf-life study of Farm Lisbon Yam (Dioscorea alata L.) Chips, J. Agr. Univ. P.R., 57 (3): 196202, 1973.

13. - $\longrightarrow$ and Gonźlez, M. A., Effect of flakes size on pasting characteristics of instant Florido yam (Dioscorea alata L.) flake slurries, J. Agr. Univ. P.R., 58 (2): 219-24, 1974.

14. Schoch, T. J., Mechano-chemistry of starch, Wallerstein Laboratories Communication, 32 (109): 149-71, 1969.

15. Smith, O., and Davis, C. O., Potato Quality. XV. Improving texture and measuring textural changes in potato flakes, Potato J. 40 (3): 67-80, 1963. 